\title{
STUDIES ON RAT TESTICULAR CELLS IN TISSUE CULTURE
}

\author{
D. M. DE KRETSER,* K. J. GATT, $\uparrow$ M. L. DUFAU $\dagger$ AND B. HUDSON \\ School of Medicine, Monash University, Clayton, Victoria, Australia
}

(Received 15th November 1969, revised 18th August 1970)

\begin{abstract}
Summary. The preparation of morphologically distinct monolayers of cells by tissue culture of dissected seminiferous tubules and of the intertubular fraction of the adult rat testis is reported. The cells comprising the monolayers obtained by tissue culture of the intertubular fraction of the testis represent interstitial cells, identification being based on light microscopy, $3-\beta$ hydroxysteroid dehydrogenase histochemistry, electron microscopy and the ability of the cells to localize ${ }^{125}$ I-labelled $\mathbf{L H}$.

The cell monolayers obtained from the dissected seminiferous tubules arise from the immediate peritubular tissue consisting of myoid cells and lymphatic endothelium. The cells show weak histochemical reactions for 3- $\beta$ hydroxysteroid dehydrogenase activity and ultrastructural features of myoid cells and fibroblasts. No localization of either ${ }^{125} \mathrm{I}$ labelled FSH or LH could be demonstrated in these cells by autoradiography.
\end{abstract}

\section{INTRODUCTION}

The contribution of individual cell types in the mammalian testis to the overall function of the organ has been difficult to assess due to problems in obtaining pure samples of each cell type. Some investigators have employed tissue culture methods in attempts to isolate testicular cell types (Kodani \& Kodani, 1966; Steinberger \& Steinberger, 1966). From cell suspensions of adult rat testes, Kodani \& Kodani (1966) obtained cell monolayers which they identified as Sertoli cells by light microscopy. Other workers (Steinberger, Steinberger, Vilar, Salamon \& Sud, 1967), using cell suspensions from 20-day-old rat testes pretreated with human chorionic gonadotrophin (HCG), obtained cell monolayers with similar light microscopic features to those of Kodani \& Kodani (1966). However, Steinberger et al. (1967), on the basis of their ultrastructural and histochemical studies, classified the cells as interstitial cells and clearly outlined the difficulty of identifying cells in tissue culture by morphological criteria.

* Present address: Department of Medicine, University of Washington, USPHS Hospital, Seattle, Washington 98114.

$\dagger$ Present address: Division of Endocrinology, Institute of Child Health and Human Development, National Institutes of Health, Bethesda, Maryland. 
The relative ease with which it is possible to dissect the adult rat testis into seminiferous tubules and an intertubular fraction rich in interstitial cells has been demonstrated previously (Christensen \& Mason, 1965; Hall, Irby \& de Kretser, 1969). The present report describes the use of this technique along with tissue culture in an attempt to isolate and study individual cell types from the rat testis. Light microscopic, histochemical, ultrastructural and autoradiographic techniques have been used to identify and study two morphologically distinct monolayers obtained from separate cultures of dissected seminiferous tubules and the intertubular fraction of the adult rat testis.

\section{MATERIALS AND METHODS}

\section{Tissue culture}

Adult albino male rats, between 100 and 150 days old, were killed by cervical dislocation or ether anaesthesia. The testes were removed aseptically, placed in Hanks' balanced salt solution and dissected free from the epididymis and testicular fat. The tunica albuginea was then opened and removed by blunt dissection.

Seminiferous tubules were separated from the main mass of tissue using No. 7 jewellers forceps (Dumont) and lengths of tubules were placed on coverslips ( 2 in. $\times 2$ in.) in Petri dishes. When approximately ten rows of tubules had been placed on coverslips, the seminiferous tubules were cut into small pieces approximately 2 to $3 \mathrm{~mm}$ in length. The Petri dish was then incubated for 20 to $30 \mathrm{~min}$ at $37^{\circ} \mathrm{C}$ in $5 \% \mathrm{CO}_{2}$ in air, before the addition of medium. This incubation was carried out to decrease the tendency of the tubular fragments to float off the coverslip when the incubation medium was added. Ten $\mathrm{ml}$ of Eagle's Minimum Essential Medium was added slowly to each culture, trying to avoid displacement of the segments of the tubules.

The cultures were subsequently incubated at $37^{\circ} \mathrm{C}$ for 7 days in a humidified incubator with a gas phase of $5 \% \mathrm{CO}_{2}$ in air and were maintained between $\mathrm{pH} 6.9$ and 7.2. After an initial period of 7 days, the medium was changed at 48-hr intervals and a number of investigations were performed in an effort to identify the cells. In some experiments, the cultures were examined at 24-hr intervals in an attempt to locate the source of the cells comprising the monolayers.

The inter-tubular fraction of the testis was suspended in Hanks' balanced salt solution and centrifuged at $1000 \mathrm{rev} / \mathrm{min}$ for $5 \mathrm{~min}$. The supernatant was discarded and the cells were resuspended in Eagle's Minimum Essential Medium. Petri dishes containing coverslips were seeded with $1 \mathrm{ml}$ of the suspension, the volume in each Petri dish being adjusted to $10 \mathrm{ml}$ with the medium. The cultures were then incubated at $37^{\circ} \mathrm{G}$ in a humidified incubator with a gas phase of $5 \% \mathrm{CO}_{2}$ in air. After incubation for 7 days, during which the cultures were maintained at a $\mathrm{pH}$ between 6.9 and 7.2 , the medium was changed at 48-hr intervals.

The cells adherent to the coverslips from both seminiferous tubule and intertubular tissue cultures were examined using the following methods. 


\section{Light microscopy}

After removal of the incubation medium, the coverslips were washed in Hanks' balanced salt solution and fixed in Bouin's fluid. Following staining with haematoxylin and eosin, the coverslips with the adherent cells were dehydrated and mounted, using a polystyrene mountant. The coverslips were then examined in a Leitz Orthoplan microscope.

\section{3- $\beta$ hydroxysteroid dehydrogenase histochemistry}

Goverslips with adherent cells were rinsed in Hanks' balanced salt solution, frozen on dry ice and dried in air. To detect 3- $\beta$ hydroxysteroid dehydrogenase (Baillie, Ferguson \& Hart, 1966), the coverslips with the attached cells were incubated in a medium which contained dehydroepiandrosterone (DHA) at a concentration of $0.25 \mathrm{mg} / \mathrm{ml}$ (final solution) dissolved in dimethyl formamide, nicotinamide $0.5 \mathrm{mg} / \mathrm{ml}$, and nicotine adenine dinucleotide $0.5 \mathrm{mg} / \mathrm{ml}$ in 0.066 M-Sorensen's phosphate buffer at $\mathrm{pH} 7 \cdot 2$. The incubation was carried out at $37^{\circ} \mathrm{C}$ for $90 \mathrm{~min}$ at $\mathrm{pH} 7 \cdot 2$. After washing in phosphate buffer and fixation in $10 \%$ neutral formalin for 10 min, the coverslips were mounted using Hydramount.

\section{Ultrastructural studies}

Following 7 days of incubation, cells from both types of cultures were removed from the coverslips by gentle rubbing after exposure to a solution of trypsin. The cells were collected by centrifugation and placed in $2.5 \%$ phosphatebuffered glutaraldehyde at $\mathrm{pH} 7.4$ in cellulose nitrate centrifuge tubes. After $1 \mathrm{hr}$, the pellets were washed in $5 \%$ phosphate-buffered sucrose and post-fixed for $1 \mathrm{hr}$ in $2.5 \%$ osmium tetroxide buffered with a potassium dichromatecalcium chloride mixture (Richardson, 1962). Dehydration was carried out in graded concentrations of acetone and the pellets were embedded in Araldite. The use of cellulose nitrate centrifuge tubes affords the advantage that as dehydration in acetone progresses the tubes are dissolved, thus facilitating the transfer of pellets into the embedding medium.

Thin sections stained with aqueous uranyl acetate (Watson, 1958) and then lead citrate (Reynolds, 1963) were examined in a Siemens Elmiskop IB.

\section{Autoradiography}

Tissue cultures, prepared as described, were examined after the following time intervals: $2 \mathrm{hr}$, and 1, 3, 4, 5 and 7 days. At each time interval, the medium was changed and the following radioactively labelled proteins were added: (i) ${ }^{125} \mathrm{I}$-labelled luteinizing hormone $(\mathrm{LH})$; (ii) ${ }^{125} \mathrm{I}$-labelled follicle stimulating hormone (FSH); (iii) ${ }^{125}$ I-labelled bovine serum albumin (BSA). Between 40 and $50 \mu \mathrm{Ci}$ of radioactively labelled protein were added to each culture. After a further $2 \mathrm{hr}$ of incubation, coverslips with adherent cells from cultures of both dissected seminiferous tubules and the intertubular fraction were rinsed thoroughly in Hanks' balanced salt solution and placed in Bouin's fixative or methanol. In some experiments, the cell monolayers were removed from the coverslips by gentle rubbing, collected by centrifugation, resuspended in $5 \%$ bovine serum albumin and smeared on glass slides. Both the smears and coverslips subsequently were dipped in Ilford $\mathrm{K}_{2}$ emulsion and then prepared for 
light microscopy according to a previously described method (de Kretser, Gatt, Burger \& Smith, 1969). The exposure periods ranged from 2 to 4 weeks.

The hormones used were highly purified human LH (Hartree, 1966) and human FSH. Iodination was performed by a modification (Gatt \& Gulross, 1968 ) of the method of Greenwood, Hunter \& Glover (1963) using ${ }^{125} I$ (Radiochemical Centre, Amersham). The iodinated hormones were further purified by adsorption to powdered cellulose (Whatman GF101) followed by elution with $1 \% \mathrm{BSA}$ in $20 \%$ acetone-barbitone buffer, $\mathrm{pH} 8.6$ (Berson \& Yalow, 1968).

\section{OBSERVATIONS}

\section{Light microscopy}

Gultures of the seminiferous tubules yielded a monolayer of cells which appeared to grow over the coverslip from the tissue explants which generally floated off after about 7 days leaving a fairly uniform monolayer.

\section{EXPLANATION OF PLATES}

\section{PLATE 1}

FIg. 1. The monolayer obtained from cultures of explants of isolated seminiferous tubules is illustrated. Arrows indicate the tails of spermatozoa which have adhered to the monolayer. $\times 125$.

Fig. 2. At higher magnification, the Type-1 cells from explants of seminiferous tubules show ovoid nuclei, multiple nucleoli and irregularly palely staining cytoplasm. Arrow indicates adherent spermatids. $\times 320$.

Frg. 3. An explant of seminiferous tubule $(T)$ after 1 day in culture shows the Type-1 cells (arrows) arising from the peritubular connective tissue sheath. The culture was exposed to $\left.{ }^{125} \mathrm{I}\right] \mathrm{FSH}$ which shows no localization in the Type-1 cells. $\times 125$.

Fig. 4. The irregular and small deposits of formazan (arrows) in Type-1 cells can be seen and indicate weak 3- $\beta$ hydroxysteroid dehydrogenase activity. $\times 500$.

\section{PLATE 2}

Frg. 5. A group of Type-2 cells from a culture of the intertubular fraction of the testis illustrates their nuclei with single nucleolus and the granular cytoplasm. $\times 290$.

Fig. 6. A mitotic figure amongst a group of Type-2 cells from a culture of the intertubular fraction of the testis is shown. Several cells contain rod-shaped crystals (arrows). $\times 360$. FIG. 7. An autoradiograph of a culture of the intertubular fraction of the testis illustrates the localization of $\left[{ }^{125} \mathrm{I}\right] \mathrm{LH}$ to the Type-2 cells (arrows). Note the lack of localization in the Type-1 cells (T). $\times 180$.

Frg. 8. Type-2 cells exhibit collections of formazan deposits indicative of $3-\beta$ hydroxysteroid dehydrogenase activity (arrows). $\times 450$.

\section{PLATE 3}

Fig. 9. Type-1 cells from a culture of seminiferous tubule explants show the elongated nucleus $(N)$, lipid inclusions $(L)$ and rough endoplasmic reticulum $(R)$. Collagen fibres (arrows) and basement membrane-like material $(B)$ can be seen. $\times 2800$.

Fig. 10. A higher magnification of a Type-1 cell shows nucleus (N), nucleolus (NL) and rough endoplasmic reticulum (R). Collagen fibres (arrows) can be seen in close association with the cells. $\times 7900$.

Fig. 11. Type-2 cells from culture of the intertubular fraction of the testis shows the nucleus (N), prominent nucleolus (NL) and cytoplasm filled with tubular agranular endoplasmic reticulum. The mitochondria (M) and irregular cell processes (arrows) can be seen. $\times 3200$.

Fig. 12. The membranous profiles of the Golgi region of a Type-2 cell are illustrated. Note the mitochondria have tubular cristae (arrows), intra-mitochondrial dense bodies and an electron-dense matrix. $\times 12,000$. 
PLA'E 1
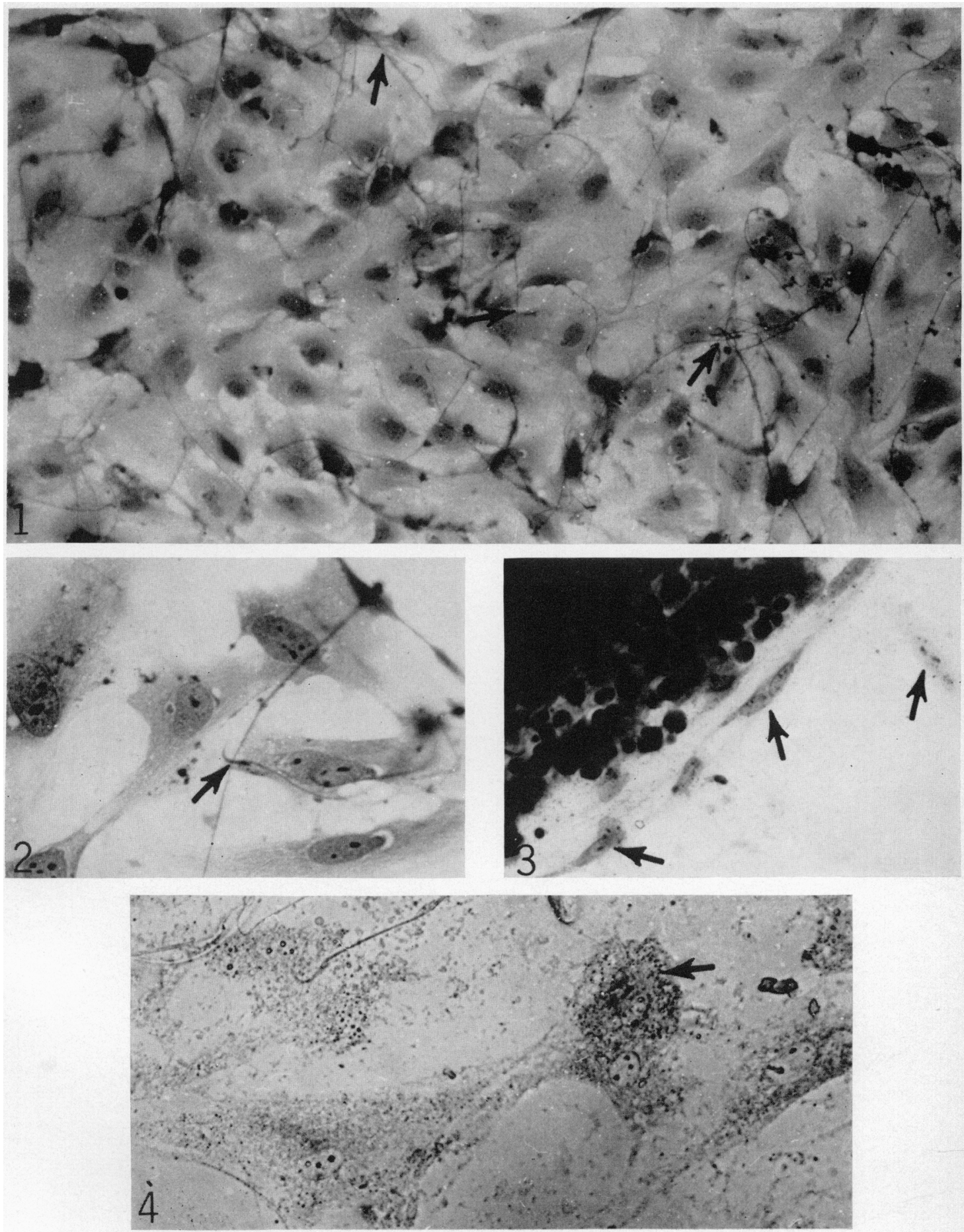

(Fincing p. 314) 
PLATE 2

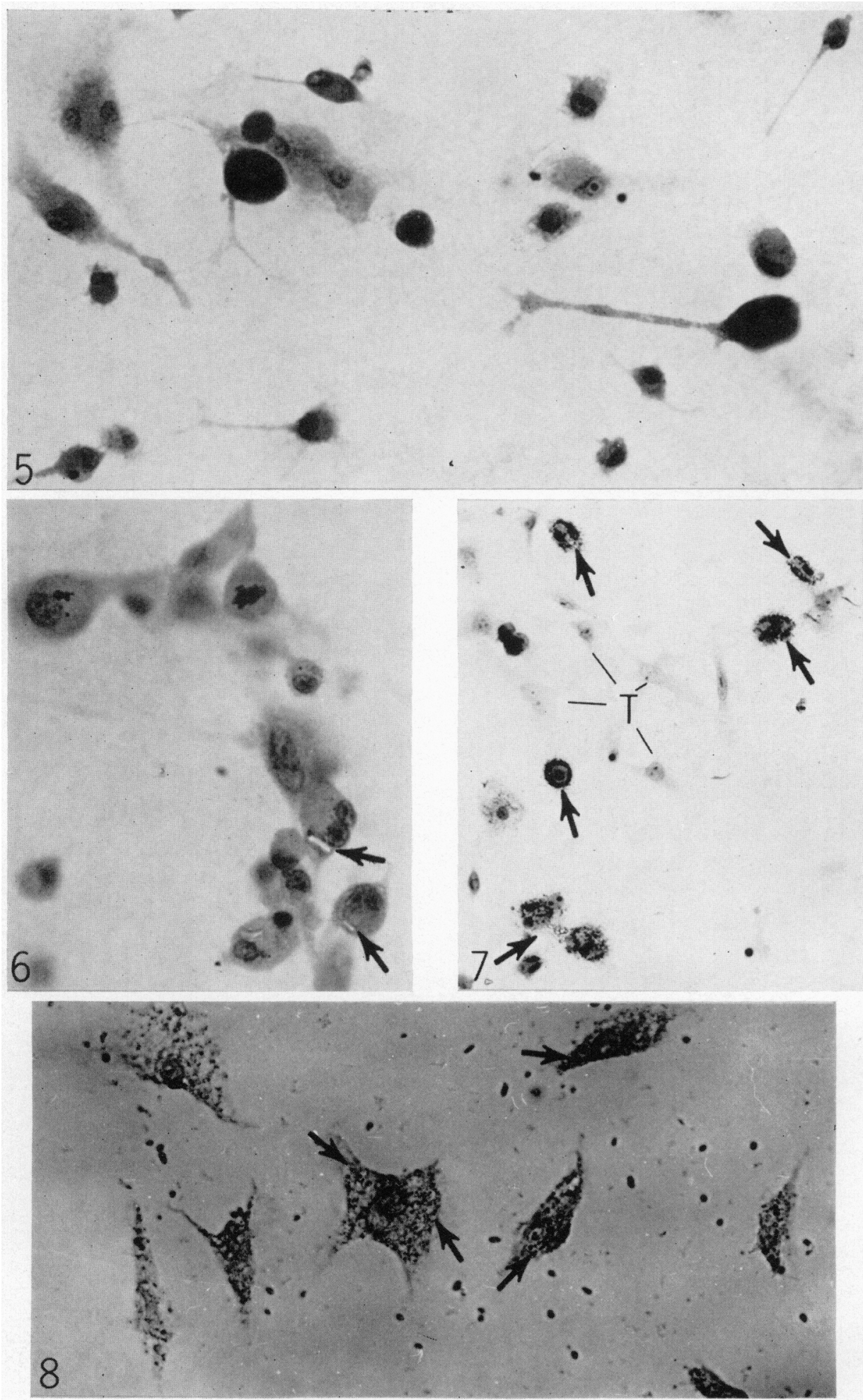


PI.STH 3

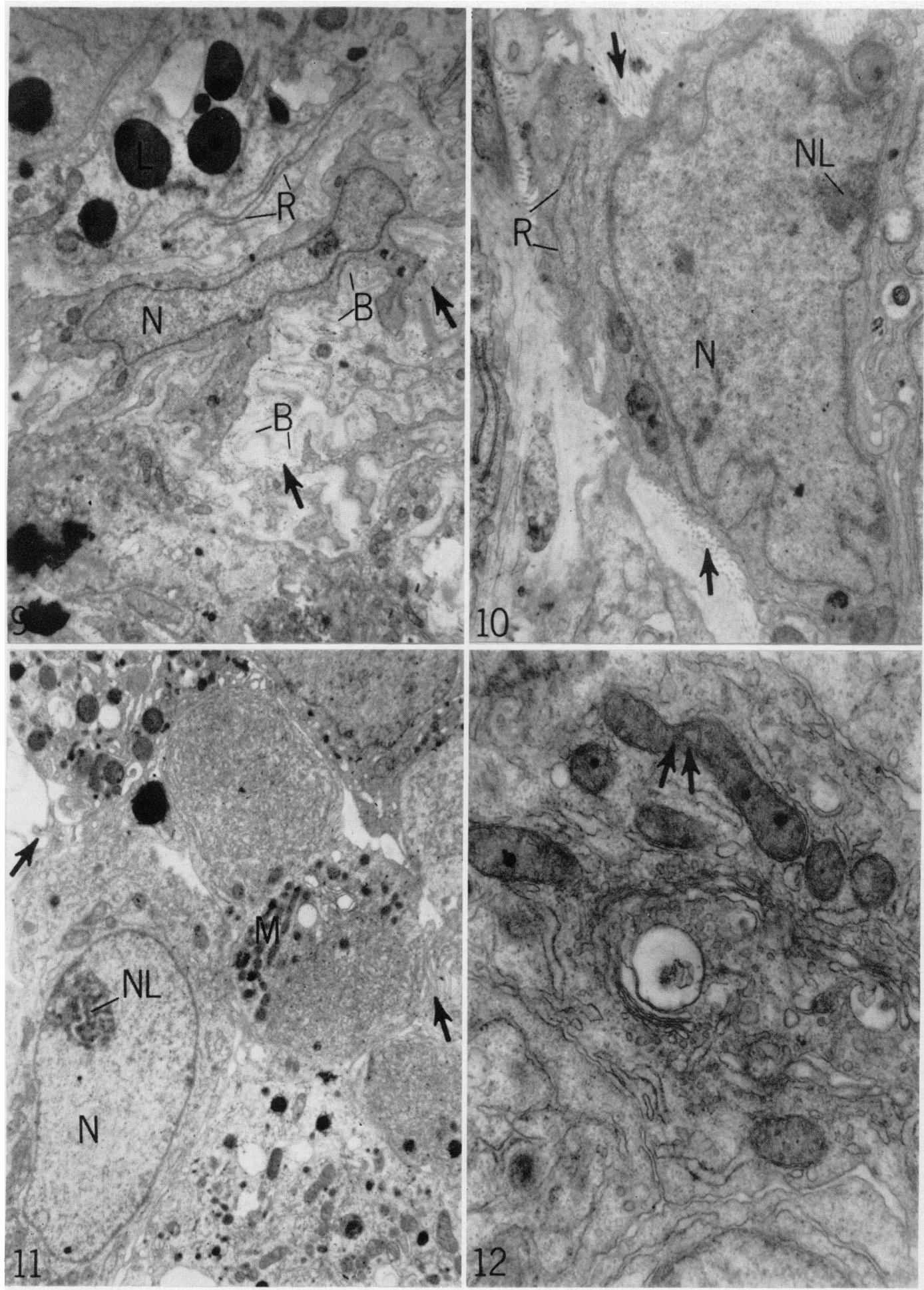


In general, the monolayer was concentrated principally around the fragments of the seminiferous tubules but later spread out over large areas of the coverslips (Pl. 1, Fig. 1). Examination revealed that the cells composing the monolayer were irregularly shaped with cytoplasm that stained poorly with haematoxylin and eosin (Pl. 1, Fig. 2). The cells, called Type 1, often exhibited the presence of fibrils and lipid aggregations in their cytoplasm (Pl. 1, Fig. 2). Their nuclei were round to oval in shape and contained several nucleoli. The Type-1 cells were the principal components of the monolayer grown from explants of the dissected seminiferous tubules. In cultures examined only 2 days after their initiation, Type-1 cells could be seen in an immediate peritubular position and arose by migration and division of cells composing the attenuated sheath of the tubule (Pl. 1, Fig. 3).

Gultures of the inter-tubular fraction, when examined after 7 days, were found to yield a monolayer growing on the coverslips. Although some cells had features that corresponded to those of Type-1 cells, the majority of cells in the monolayer were morphologically different. These cells, termed Type-2 cells, were more circumscribed and their cytoplasm was more eosinophilic than that of Type-1 cells (Pl. 2, Figs. 5, 6). The nuclei of the Type-2 cells were smaller than those of Type-1 cells and contained prominent nucleoli. Occasionally, some Type-2 cells contained poorly staining crystals in their cytoplasm (Pl. 2, Fig. 6) and were sometimes found aggregated together forming multinucleate collections. Mitotic figures were seen frequently (Pl. 2, Fig. 6). Some Type-1 cells were present in cultures from the intertubular fraction.

\section{3- $\beta$ hydroxysteroid dehydrogenase histochemistry}

Both the Type-1 and Type-2 cells showed some deposition of formazan crystals, indicating the presence of 3- $\beta$ hydroxysteroid dehydrogenase in their cytoplasm. The deposits of formazan were larger and more frequently found in the Type-2 cells (Pl. 2, Fig. 8). In general, the reaction in Type-1 cells was poor and some cells showed no formazan deposits (Pl. 1, Fig. 4).

\section{Ultrastructural studies}

Studies on monolayers composed principally of Type-1 cells revealed that they were surrounded in many areas by collagen fibres and a moderately electron-dense amorphous 'basement membrane' like material (Pl. 3, Figs. 9, 10). Their nuclei were elongated and occasional cells contained a small nucleolus. The cytoplasm contained a few profiles of rough endoplasmic reticulum and many fine intracellular filaments approximately 40 to $60 \AA$ in width. In some areas, the rough endoplasmic reticulum was more prominent, resembling that seen in fibroblasts. Some cells contained small collections of smooth-surfaced membranous vesicles and electron-dense inclusions identified as lipid. In others, the perinuclear cytoplasm was extremely sparse. In general, many of the cells resembled the peritubular contractile cells described in earlier studies (Leeson \& Leeson, 1963; Ross, 1967).

The ultrastructural features of Type-2 cells in monolayers derived from the intertubular fraction of the testis were clearly different from those of Type-1 cells. The nuclei of the Type-2 cells were oval and contained prominent nucleoli 
(Pl. 3, Fig. 11). The cytoplasm was abundant and contained large quantities of smooth endoplasmic reticulum, both tubular and vesicular in form. In some areas, the tubular agranular endoplasmic reticulum was present as whorls in the cytoplasm. Some cells contained lipid inclusions and, in many, the cell surface revealed thin pseudopodia. The mitochondria contained tubular cristae and showed active Golgi complexes (Pl. 3, Fig. 12).

\section{Autoradiographic studies}

The Type-1 cells failed to localize or concentrate either $\left[{ }^{125} \mathrm{I}\right] \mathrm{FSH},\left[{ }^{125} \mathrm{I}\right] \mathrm{LH}$ or $\left[{ }^{125} \mathrm{I}\right] \mathrm{BSA}$ at any of the time periods at which they were studied (Pl. 1, Fig. 3).

The Type-2 cells demonstrated localization of $\left[{ }^{125} \mathrm{I}\right] \mathrm{LH}$ at all stages examined from $2 \mathrm{hr}$ to 7 days in culture. The localization was principally cytoplasmic and many cells revealed heavy concentration of the label in their peripheral cytoplasm (Pl. 2, Fig. 7). Although the Type-2 cells failed to localize $\left[{ }^{125} \mathrm{I}\right] \mathrm{BSA}$, there was some localization of $\left[{ }^{125} \mathrm{I}\right] \mathrm{FSH}$ which appeared to be less intense than with $\left[{ }^{125} \mathrm{I}\right] \mathrm{LH}$ and only occurred in the experiments using one of the preparations of $\left[{ }^{125} \mathrm{I}\right] \mathrm{FSH}$.

\section{DISGUSSION}

This study demonstrates that it is possible to derive a monolayer of cells in tissue culture from either the seminiferous tubular fraction or the intertubular fraction of the adult rat testis. Previous investigators did not separate the major tissue components of the rat testis but seeded their culture with a mixture of cells both of tubular and intertubular origin (Kodani \& Kodani, 1966; Steinberger \& Steinberger, 1966). From this mixture, they obtained cell monolayers which have been interpreted as being Sertoli cells by one group (Kodani \& Kodani, 1966) and interstitial cells by the other group (Steinberger \& Steinberger, 1966). The results of the present study confirm that it is possible to obtain monolayers of cells from the adult rat testis and are contrary to the findings of Steinberger \& Steinberger (1966) who experienced difficulty in producing monolayers in tissue culture from the adult rat testis and for this reason used testes from 20 -day-old rats pretreated with HCG.

Separation of the components of the rat testis by dissection has been used to study the steroid biosynthetic ability of both the seminiferous tubules and the interstitial cells (Ghristensen \& Mason, 1965; Hall et al., 1969). These studies established that the seminiferous tubular fraction contained minimal interstitial cell contamination whereas the intertubular fraction was rich in interstitial cells. The observation that Type-2 cells are derived from the intertubular fraction therefore suggests that they may well be interstitial cells. Although morphological criteria of cells in tissue culture must be interpreted carefully, the Type- 2 cells retain many of the features of interstitial cells, namely the round nucleus with a prominent nucleolus and the granular eosinophilic cytoplasm.

The demonstration of 3- $\beta$ hydroxysteroid dehydrogenase activity in the Type- 2 cells is further support that they are interstitial cells. The finding of large quantities of agranular endoplasmic reticulum demonstrated ultra- 
structurally in the Type-2 cells is further evidence indicative that these are interstitial cells in culture. The ability of the Type- 2 cells to localize $\left[{ }^{125} \mathrm{I}\right] \mathrm{LH}$ is almost conclusive evidence that they are interstitial cells. In acute studies in vitro, using the intertubular fraction of the rat testis, it has been shown that the interstitial cells will localize or bind $\left[{ }^{125} \mathrm{I}\right] \mathrm{LH}$ and that this binding can be inhibited by previous exposure to unlabelled LH (de Kretser, Catt \& Paulsen, 1970). Earlier studies in vivo also demonstrated the selective ability of the

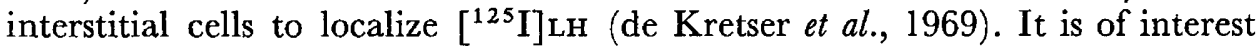
that the ability of the interstitial cells to concentrate $\left[{ }^{125} \mathrm{I}\right] \mathrm{LH}$ persists in tissue culture for at least 7 days. The use of techniques involving the ability of cells to localize specific markers may represent a valuable tool in their identification, especially in tissue culture systems where morphological features may be altered. In addition, this method of obtaining interstitial cells in tissue culture will allow their steroid metabolic capacity to be investigated.

The finding that the Type-1 cell monolayers obtained from explants of the seminiferous tubules arise from the peritubular connective tissue is of interest. Recently, this sheath has been shown to consist of myoid or contractile cells and the endothelial lining of lymphatic capillaries (Fawcett, Heidger \& Leak, 1969). It seems likely that the plane of separation of the two fractions of the testis probably passes through the easily disrupted lymphatics as it is impossible to remove the myoid sheath without interrupting the integrity of the seminiferous tubules. The ultrastructural features of many Type- 1 cells are similar to those of the contractile or myoid cells and is further evidence that they arise from the peritubular sheath.

The morphology of the Type-1 cells by light microscopy corresponds closely to the cells identified by Kodani \& Kodani (1966) as Sertoli cells. However, their evidence consisted mainly of light microscopic studies and the difficulty of obtaining positive identification by such criteria has been emphasized by Steinberger et al. (1967). Further evidence that the Type-1 cells are not Sertoli cells is their failure to localize labelled FSH as earlier studies by Mancini and his co-workers suggest that Sertoli cells will localize labelled FSH (Mancini, Castro \& Seigeur, 1967).

Further investigations have shown that monolayers of Type-1 cells have the ability to convert DHA to testosterone but fail to metabolize pregnenolone to testosterone (Dufau, de Kretser \& Hudson, 1970). This steroid metabolic capacity is of interest in view of suggestions that the precursors of interstitial cells are derived from the peritubular mesenchymal cells (Mancini, Vilar, Lavieri, Andrada \& Heinrich, 1963). Further, the failure of the Type-1 cells to localize $\left[{ }^{125} \mathrm{I}\right] \mathrm{LH}$ is in keeping with the inability of HCG to alter or stimulate the steroid metabolic potential of the Type-I cells (Dufau et al., 1970).

\section{AGKNOWLEDGMENTS}

Highly purified human LH and human FsH were kindly donated by Dr B. B. Saxena and Dr L. E. Reichert.

The authors gratefully acknowledge the assistance of Miss E. Rost and $\mathrm{Mr}$ J. S. Simmons in the preparation of the illustrations. The studies were partly 
supported by grants from the National Health and Medical Research Council of Australia and the preparation of the manuscript was completed during tenure of a U.S. Public Health Service International post-doctoral fellowship No. F05 TW1572.

\section{REFERENCES}

Baillie, A. H., Ferguson, M. M. \& HARt, D. McK. (1966) Developmenis in steroid histochemistry. Academic Press, London and New York.

Berson, S. A. \& YALOW R. S. (1968) Human growth hormone labeled with radioactive iodine at high specific activity: preparation, purification and characterization for immunochemical studies and immunoassay. In: Growth Hormone, p. 47. Eds. E. Pecile and E. Muller. Excerpta Medica, Amsterdam.

Catt, K. J. \& Gulross, J. (1968) A disposable radioiodination pipette. Analyt. Biochem. 26, 207.

Christensen, A. K. \& Mason, N. R. (1965) Comparative ability of seminiferous tubules and interstitial tissue of rat testes to synthesize androgen from progesterone $-4-{ }^{14} \mathrm{C}$ in vitro. Endocrinology, 76, 646 .

de Kretser, D. M., Catt, K. J., Burger, H. G. \& Smith, G. G. (1969) Radioautographic studies on the localization of ${ }^{125}$ I-labelled human luteinizing and growth hormone in immature male rats. F. Endocr. 43, 105.

de Kretser, D. M., Catt, K. J. \& Paulsen, C. A. (1970) Studies on the in-vitro testicular binding of iodinated luteinizing hormone in rats. Endocrinology (in press).

Dufau, M. L., DE KRETSER, D. M. \& Hudson, B. (1970) Steroid metabolism by cell monolayers from peritubular tissue of isolated rat seminiferous tubules in culture. Proceedings of 52nd Meeting of the Endocrine Society, p. 89.

FawcetT, D. W., Heidger, P. M. \& Leak, L. V. (1969) Lymph vascular systems of the interstitial tissue of the testis as revealed by electron microscopy. F. Reprod. Fert. 19, 109.

Greenwood, F. C., Hunter, W. M. \& Glover, J. S. (1963) The preparation of ${ }^{131}$ I-labelled human growth hormone of high specific radioactivity. Biochem. 7. 89, 114.

Hall, P. F., IRBY, D. C. \& DE KRETSER, D. M. (1969) Conversion of cholesterol to androgens by rat testes: comparison of interstitial cells and seminiferous tubules. Endocrinology, 84, 488.

Hartree, A. S. (1966) Separation and partial purification of the protein hormones from human pituitary glands. Biochem. F. 100, 754.

Kodani, M. \& Kodani, K. (1966) The in vitro cultivation of mammalian Sertoli cells. Proc. natn. Acad. Sci. U.S.A. 56, 1200.

LeEson, C. R. \& LEEson, T. S. (1963) The postnatal development and differentiation of the boundary tissue of the seminiferous tubule of the rat. Anat. Rec. 147, 243.

Mancini, R. E., Gastro, A. \& Selgeur, A. C. (1967) Histological localization of follicle stimulating and luteinizing hormones in the rat testis. F. Hislochem. Cytochem. 15, 516.

Mancini, R. E., Vilar, O., Lavieri, J. D., Andrada, J. A. \& Heinrich, J. J. (1963) Development of Leydig cells in the normal human testis. A cytological, cytochemical and quantitative study. Am. 7. Anat. 112, 203.

REYNolds, E. S. (1963) The use of lead citrate at high $\mathrm{pH}$ as an electron opaque stain in electromicroscopy. 7. Cell Biol. 17, 208.

Richardson, K. C. (1962) The fine structure of autonomic nerve endings in smooth muscle of the rat vas deferens. F. Anat. 96, 427.

Ross, M. H. (1967) The fine structure and development of the peritubular contractile cell component in the seminiferous tubules of the mouse. Am. F. Anat. 121, 523.

Steinberger, A. \& Steinberger, E. (1966) In vitro culture of rat testicular cells. Expl Cell Res. 44, 443.

Steingerger, E., Steingerger, A., Vilar, O., Salamon, I. I. \& Sud, B. N. (1967) Microscopy, cytochemistry and steroid biosynthetic activity of Leydig cells in culture. Ciba Fdn Colloq. Endocr. 16, 56.

Watson, M. L. (1958) Staining of tissue sections for electron microscopy with heavy metals. F. biophys. biochem. Cytol. 4, 475. 